\title{
Review
}

\section{Bacteriocins of propionic acid bacteria}

\author{
Helge HolO ${ }^{\mathrm{a}} *$, Therese FAYE ${ }^{\mathrm{c}}$, Dag Anders BREDE ${ }^{\mathrm{a}}$, \\ Trine NILSEN ${ }^{\mathrm{a}}$, Inger ØDEGÅRD ${ }^{\mathrm{b}}$, Thor LANGSRUD ${ }^{\mathrm{c}}$, \\ Johanne BRENDEHAUG ${ }^{b}$, Ingolf F. NES ${ }^{a}$
}

\author{
${ }^{a}$ Laboratory of Microbial Gene Technology, Agricultural University of Norway, \\ PO Box 5051, 1432 Ås, Norway \\ ${ }^{\mathrm{b}}$ Norwegian Dairies Association, Centre for Research and Development, Oslo, Norway \\ ${ }^{\mathrm{c}}$ Department of Food Science, Agricultural University of Norway, \\ PO Box 5036, 1432 Ås, Norway
}

\begin{abstract}
Dairy propionibacteria produce a number of inhibitory compounds like propionate, acetate and diacetyl. In addition, a number of strains produce bacteriocins. Unlike lactic acid bacteria, they often produce compounds that inhibit Gram (-) bacteria as well as yeasts and molds. These dairy propionibacteria are food-grade organisms and their bacteriocins may be of interest as food preservatives. Some of their bacteriocins have been characterized. Most are heat-stable peptides containing less than 100 amino acid residues. They are insensitive to large variations in $\mathrm{pH}$, and lactic acid bacteria are often more sensitive to the bacteriocins than propionibacteria. However, at present only bacteriocins with inhibitory spectra restricted to propionibacteria have been fully sequenced. Most of the bacteriocins are produced in very low amounts when the cells are grown in liquid culture, which limits their usefulness in practical applications.
\end{abstract}

\section{propionibacteria / bacteriocin / biopreservative / food safety / food spoilage microorganism}

Résumé - Bactériocines des bactéries propioniques. Les bactéries propioniques laitières produisent plusieurs composés inhibiteurs tels que propionate, acétate, diacétyle. De plus, certaines souches produisent des bactériocines. Contrairement aux bactéries lactiques, elles produisent souvent des composés qui inhibent les bactéries Gram(-) aussi bien que les levures et moisissures. Ces bactéries propioniques laitières sont des organismes « alimentaires » et leurs bactériocines peuvent présenter un intérêt comme conservateur alimentaire. Certaines de leurs bactériocines ont été caractérisées. La plupart sont des peptides thermostables contenant moins de 100 acides aminés. Elles sont résistantes à de larges variations de $\mathrm{pH}$, et les bactéries lactiques sont souvent plus sensibles aux bactériocines

Oral communication at the 3rd International Symposium on Propionibacteria, Zurich, Switzerland, July 8-11, 2001.

* Correspondence and reprints

Tel.: (47) 64949468; fax: (47) 64941465; e-mail: Helge.Holo@ikb.nlh.no 
que les bactéries propioniques. Cependant, actuellement, seules des bactériocines avec un spectre d'inhibition limité aux bactéries propioniques ont été totalement séquencées. La plupart des bactériocines sont produites en très faible quantité quand les cellules sont cultivées en culture liquide, ce qui limite leurs applications pratiques.

\section{bactérie propionique / bactériocine / bioconservateur / sécurité alimentaire / microorganisme contaminant}

\section{INTRODUCTION}

Bacteriocins were originally defined as peptides or proteins that kill bacteria closely related to the producer strain [39]. However, many of the bacteriocins of Gram(+) bacteria show very broad inhibitory spectra. The most studied is nisin, produced by strains of Lactococcus lactis. This bacteriocin is inhibitory to most Gram $(+)$ bacteria and can also kill Gram(-) bacteria when their outer membrane has been permeabilized [35]. These findings indicate a potential for bacteriocins from $\mathrm{Gram}(+)$ bacteria as useful antimicrobial agents. The idea of using food-grade microorganisms (mainly lactic acid bacteria) to kill or inhibit pathogenic or spoilage microflora has been used for centuries in food preservation. The main inhibitory principle is acid formation. However, this is not always sufficient to prevent spoilage and growth of pathogens. Bacteriocins represent an additional hurdle, and are attractive replacements for chemical food preservatives. A major inducement of this research has been the designation of GRAS status to the bacteria as well as nisin and a growing concern for food safety and skepticism towards the use of chemical food preservatives.

During the last decade several research programs in Europe and elsewhere have focused on the exploitation of bacteriocins from lactic acid bacteria (LAB), and the field of bacteriocins of lactic acid bacteria has exploded. From only one well defined bacteriocin (nisin) in 1988, now more than fifty LAB bacteriocins have been described at the molecular level $[15,25]$. The LAB bacteriocins cover bacteriocins with very narrow inhibitory spectra, while others like nisin inhibit virtually all Gram(+) bacteria.

Propionic acid bacteria (PAB) produce metabolites with antimicrobial activity such as propionic acid, acetic acid and diacetyl [4]. The biopreservative Microgard is skim milk pasteurized after fermentation with $P$. freudenreichii ssp. shermanii [40]. It has been approved by the Food and Drug Administration for use in products like cottage cheese and yogurt [36]. Microgard inhibits some fungi and Gram(-) bacteria, but not $\operatorname{Gram}(+)$ bacteria [1]. According to Daeschel [4] about 30\% of the cottage cheese produced in the United States was made with Microgard as a preservative. The antimicrobial activity of Microgard can be ascribed to the presence of fermentation products like propionic and acetic acid in combination with a peptide with a molecular mass of about $700 \mathrm{~g} \cdot \mathrm{mol}^{-1}[1]$.

Another commercial product is BioProfit, which contains Lactobacillus rhamnosus LC 705 and Propionibacterium freudenreichii JS. Used as a protective culture $\left(10^{7}\right.$ cells per gram) the product is reported to inhibit yeasts in dairy products, and Bacillus spp. in sourdough bread. The inhibitory effects are due to synergistic activities between the two strains [38].

Products like Microgard and BioProfit have only demonstrated a part of the antimicrobial potential of PAB. Propionic acid bacteria have also been found to produce antiviral peptides [9, 29-32] and several bacteriocins. 


\section{SCREENING FOR BACTERIOCIN ACTIVITY}

Bacteriocin production is usually detected by a deferred method in which the bacteriocin producer is first grown as a colony on an agar plate before the indicator organism is added in a soft agar overlay. Bacteriocin production is then manifested by zones of growth inhibition around the colony. The first reports on PAB bacteriocins concerned bacteriocins from cutaneous propionibacteria $[8,17,28]$. Bacteriocin production among "classical" or "dairy" PAB was first studied by Grinstead [11]. Screening of 150 strains using 10 different PAB strains as indicators yielded several cultures that inhibited at least one of the indicators. Among the strains shown to be bacteriocin producers were $P$. jensenii $\mathrm{P} 126$, the producer of jenseniin G, and $P$. thoenii P127, the producer of propionicin PLG-1. During the study of jenseniin G [12] it was found that Lactobacillus delbrueckii ssp. lactis ATCC 4797 was much more sensitive to the bacteriocin than were the propionic acid bacteria.

In a later screening this strain along with other lactobacilli and PAB were used as indicators [33]. Eight of the thirteen strains tested positive against at least one indicator, but three of them were only active against lactobacilli.

Miescher [23] screened 102 PAB isolates for antimicrobial activity. In the screening she used as indicators 16 different PAB in addition to several Gram $(+)$ and Gram(-) bacteria as well as a number of yeasts and molds. With such a large test panel, most strains showed inhibition of at least one indicator organism. Interestingly, the indicators that were inhibited by most strains were lactic acid bacteria. The strains Lactobacillus delbrueckii ssp. bulgaricus DSM 20081 and Lactococcus lactis ssp. cremoris AC1 were both inhibited by about $50 \%$ of the PAB stains, and only $30 \%$ of the
PAB strains did not inhibit either of them. Seven of the isolates inhibited at least one $P$. freudenreichii strain. Interestingly, none of the strains that showed inhibition of a P. freudenreichii strain were inhibitory to Lactobacillus delbrueckii ssp. bulgaricus DSM 20081 and Lactococcus lactis ssp. cremoris AC1.

These results clearly show that several inhibitory compounds with different inhibitory spectra were produced. The study also demonstrates the importance of including many indicator strains in a screening. The use of Lactobacillus delbrueckii ssp. bulgaricus DSM 20081 and Lactococcus lactis ssp. cremoris AC1 permitted the demonstration of antimicrobial activity that otherwise would have been overlooked. Bearing in mind that certain LAB can be very sensitive indicators to $\mathrm{PAB}$ bacteriocins [12], it is very likely that strains only showing activity against these two strains produced low levels of bacteriocin under the conditions used.

In a project supported by the Nordic Industrial Fund we performed a screening of more than 100 PAB isolates. Unlike in the screenings mentioned above the PAB were grown on M17 plates instead of sodium lactate agar. Of the isolates 88 were identified to the species level by $16 \mathrm{~S}$ rRNA sequencing. Four of the strains were identified as P. acidipropionici, 11 P. thoenii, 21 P. jensenii and 52 were $P$. freudenreichii. All the $P$. acidipropionici and $P$. thoenii strains showed inhibitory activity against the indicator strain P. freudenreichii. So did 19 of the $P$. jensenii strains, but only six of the $P$. freudenreichii produced inhibitory zones in the test (unpublished results).

\section{PRODUCTION IN LIQUID MEDIA}

Although bacteriocin production is fairly common and easily detectable in PAB grown on solid media, it has proved 
difficult to demonstrate high bacteriocin production in liquid media. In general, production in liquid media is poor compared to that produced on solid media. Since a high production is crucial for purification and characterization as well as for applications, it is of vital importance to learn which factors affect the level of bacteriocin production.

Lyon and Glatz [19] grew P. thoenii P127 in NLB and found that production of propionicin PLG-1 was so low that activity could only be detected in concentrated culture supernatant samples. The highest activities were found in cultures grown at $\mathrm{pH} 7.0$, about a week after the onset of the stationary phase.

Using a modified assay with the more sensitive indicator Lactobacillus delbrueckii subsp. lactis ATCC 4797 [14], Paik et al. [27] studied the effects of growing the producing strain P127 in a fed batch reactor. By using a fed batch strategy they were able to increase cell density and to improve the yield of propionicin PLG-1 about twenty times to $180 \mathrm{AU}$ (activity units) or BU (bacteriocin units) per mL. Again, detectable activity could only be demonstrated late in growth and reached a maximum after $14 \mathrm{~d}$, followed by loss of activity.

In liquid culture of $P$. jensenii P126 jenseniin $G$ activity could initially be detected only in hundred-fold concentrated samples and only from stationary phase cells
[12]. Ekinci and Barefoot [6] found that the optimal $\mathrm{pH}$ for jenseniin $\mathrm{G}$ production was about 6.4. At the highest about $200 \mathrm{BU} \cdot \mathrm{mL}^{-1}$ was produced. The detection limit in their assay was $100 \mathrm{BU} \cdot \mathrm{mL}^{-1}$. To detect bacteriocin activity at low concentrations they used ammonium sulfate precipitation. This precipitation was far from quantitative, but allowed bacteriocin production to be studied throughout growth. From this work it was clear that maximal production also took place many days after the onset of the stationary phase for this bacteriocin.

In both these cases production could initially be demonstrated only long after the onset of the stationary phase. Probably production is under genetic control, but it does not necessarily mean that transcription from the bacteriocin promoters only takes place in the stationary phase. As shown in Figure 1 the bacteriocin from $P$. thoenii 159 is detectable in the supernatant in the stationary phase. However, initially the activity is bound to the cells and later released into the medium (Brede et al., unpublished).

Ratman et al. [33] also reported that extracellular bacteriocin could only be detected in the late stationary phase of $P$. jensenii B1264. These researchers suggested that cell lysis occurred and that the bacteriocin was released during lysis.

Propionicin T1 is the only known PAB bacteriocin that is produced in easily

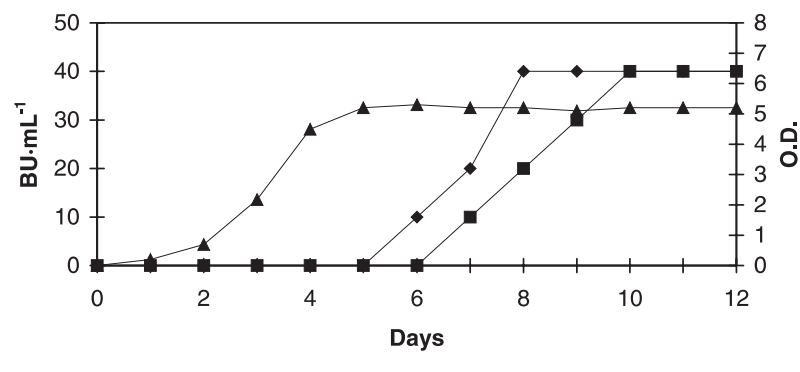

Activity in supernatant $\rightarrow-$ Cell bound activity $\rightarrow-$ O.D.

Figure 1. Growth and bacteriocin production of $P$. thoenii T159. 


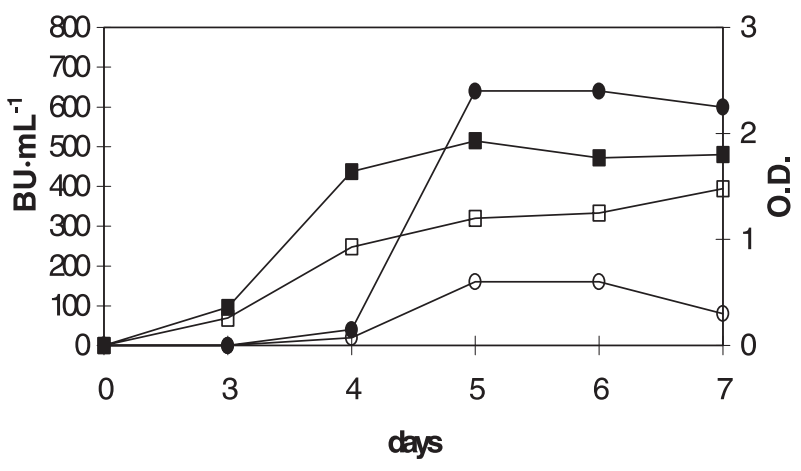

$-0-2792$ activity $\rightarrow-419$ activity $\square-2792$ grouth -4 -419 grouth

Figure 2. Production of propionicin T1 during growth of P. thoenii 419 and P. thoenii LMG 2792.

detectable amounts during growth [7]. Two strains, $P$. thoenii 419 and $P$. thoenii LMG 2792 both produce this bacteriocin. As shown in Figure 2 bacteriocin production is not constitutive, but unlike other PAB it reaches a maximum before the onset of the stationary phase. No production is seen in the stationary phase. This pattern is the same for both strains. However, as shown in Figure 2 strain 419 grows to a higher density and produces more bacteriocin than strain LMG 2792. Furthermore, while strain 419 produced bacteriocin at $30{ }^{\circ} \mathrm{C}$, bacteriocin production by strain LMG 2792 was only observed at lower growth temperatures $\left(22^{\circ} \mathrm{C}\right)$. The highest activity found, $640 \mathrm{BU}$ (bacteriocin units) per $\mathrm{mL}$, is 160 times the detection limit in the assay used.

\section{PURIFICATION AND PROPERTIES OF THE BACTERIOCINS}

\subsection{Propionicin PLG-1}

Strain P. thoenii P127 (ATCC 4874) was discovered as a bacteriocin producer during screening of several PAB isolates [11].
Lyon and Glatz [18] were not able to obtain bacteriocin production in liquid media, but extracted the bacteriocin from solid medium on which strain P127 had been grown. Their extracted bacteriocin did not show any activity against strains of $P$. freudenreichii, but was active against $P$. thoenii, $P$. jensenii and $P$. acidipropionici. The viable count of the sensitive strain $P$. thoenii P5 was reduced by $99.6 \%$ by the extract. The activity of this extract was protease-sensitive, and moderately thermostable $\left(80{ }^{\circ} \mathrm{C}, 30 \mathrm{~min}\right)$. Furthermore, the extract was inhibitory to several lactic acid bacteria and some Gram(-) bacteria, yeasts and molds. Several typical food-borne pathogens and spoilage organisms belonging to the genera Bacillus, Staphylococcus, Clostridium, Yersinia and Salmonella were found to be insensitive [18]. As for jenseniin G, Lactobacillus delbrueckii ssp. lactis ATCC 4797 was the most sensitive strain [14].

The bacteriocin was purified by Lyon and Glatz [18, 19], and their procedures were modified and refined by Paik and Glatz [26]. The cells were grown for $14 \mathrm{~d}$ in sodium lactate broth at $32{ }^{\circ} \mathrm{C}$ and at constant $\mathrm{pH}$ 7.0. Purification of the bacteriocin involved ammonium sulfate precipitation of the culture supernatant, binding of 
precipitated proteins to a cation exchanger at $\mathrm{pH} 6.5$ and elution by a salt gradient. The active fraction was thereafter concentrated by dialysis against solid polyethylene glycol and subjected to reverse phase HPLC. The activity eluted late in the elution gradient, indicating a highly hydrophobic compound. The recovery of activity was close to $100 \%$ for the whole procedure. Although minor components were also detected, the active fractions from the reverse phase chromatography step were all dominated by a $9.7 \mathrm{~kg} \cdot \mathrm{mol}^{-1}$ peptide. The peptide was estimated to contain 99 amino acids and Nterminal sequencing gave the following sequence:

$$
\text { N-V-D-A(T)-R-T(C)-A(T)-R-T(A)-P. }
$$

This sequence did not share homology with any proteins in the sequence databases. From the data presented by Paik and Glatz [26] it can be calculated that the culture produced about $2 \mathrm{mg} \cdot \mathrm{L}^{-1}$ of the peptide. However, the activity was low. The cultures showed an activity of $2.5 \mathrm{AU} \mathrm{mL}^{-1}$. The specific activity of the purified peptide was $2 \mathrm{AU} \cdot \mu \mathrm{g}^{-1}$, which is three orders of magnitude less than what is seen for bacteriocins from lactic acid bacteria $[3,13$, 21] and propionicin $\mathrm{T} 1$.

Gollop and Lindner [10] used Lactobacillus delbrueckii ssp. lactis to investigate the mode of action of propionicin PLG-1. Most LAB bacteriocins studied cause efflux of potassium ions from sensitive cells. Propionicin PLG-1, however, did not cause efflux of potassium ions or UVabsorbing material from the sensitive Lactobacillus strain, while nisin did. The authors concluded that propionicin PLG-1 has a mode of action previously not seen with other bacteriocins. It was shown that the bacteriocin interfered with the glycolysis of the target organism, and it was suggested that the bactericidal effect could be ascribed to inhibition of metabolism.

Strain P127 could produce propionicin PLG-1 in skim milk. Psychrotrophic spoilage or pathogenic organisms like Listeria monocytogenes, Pseudomonas fluorescens, Vibrio parahaemolyticus and Yersinia enterocolitica were killed or inhibited when inoculated into skim milk fermented by strain P127 and incubated at $10^{\circ} \mathrm{C}$. A mutant of strain P127 that did not produce bacteriocin did not affect the growth of the spoilage or pathogenic strains. The authors suggested a potential for propionicin PLG-1 as a food preservative [20].

\subsection{Jenseniin $G$}

This bacteriocin is produced by $P$. jensenii (now identified as $P$. thoenii) P126 (ATCC 4872) [11]. Only two of the ten PAB strains tested were sensitive to jenseniin $G$ [12], while both the lactococcal strain tested and 3 out of ten lactobacilli were sensitive. The strain $L$. delbrueckii ssp. lactis ATCC 4797 was much more sensitive towards jenseniin $G$ than was the initial indicator, P. acidipropionici P5. Twenty times more bacteriocin was needed to inhibit the PAB strain than the Lactobacillus strain. Grinstead and Barefoot [12] showed that after exposing L. delbrueckii to the bacteriocin most of the activity could no longer be detected in the extracellular liquid. Probably the bacteriocin was bound to the cells, even when in excess. Lactic acid bacteria have a potential to bind large amounts of cationic and hydrophilic peptides such as LAB bacteriocins [42], probably to the negatively charged teichuronic and lipoteichuronic acids in their walls. In their assays Grinstead and Barefoot [12] could not demonstrate a significant binding of the bacteriocin to $P$. acidipropionici P5. It is likely that the better ability to bind and thus locally concentrate the bacteriocin explains why the lactic acid bacterium was more sensitive to the bacteriocin than the propionic acid bacterium.

Other than PAB, lactococci and lactobacilli, no other sensitive bacteria, yeasts or molds were found, but in a later work cited by Ekinci [6] it was reported that 
jenseniin $G$ inhibited the outgrowth of clostidial spores.

Jenseniin $G$ is bacteriostatic to P. acidipropionici $\mathrm{P} 5$, but bactericidal to the more sensitive $L$. delbrueckii ssp. lactis ATCC 4797. Unlike propionicin PLG-1 it is heat-stable and withstands $100{ }^{\circ} \mathrm{C}$ for $15 \mathrm{~min}$ [12]. It has been suggested that jenseniin $\mathrm{G}$ can prevent overacidification of yogurt, since application of $20-60 \mathrm{AU} \cdot \mathrm{mL}^{-1}$ inhibited acid formation in simulated yogurt [41].

\subsection{Propionicin SM1 and SM2}

In a screening of 102 PAB $P$. jensenii DF1 was found to inhibit yeasts $(15 / 24)$, molds (3/4), PAB (2/16) and lactic acid bacteria (1/11) [23]. No inhibition of Gram(-) bacteria was seen for this strain. Despite the fairly broad spectrum of inhibition, only the most sensitive indicator strain, $P$. jensenii DSM20274, was inhibited by the culture supernatant [24]. This strain was thus used as indicator during the purification of the antimicrobial activities.

By using SDS-PAGE the antibacterial activities of strain DF1 could be separated into two distinct fractions with antimicrobial activity [24]. The two bacteriocins, designated propionicin SM1 and SM2, were purified by a procedure involving ultrafiltration, cation exchange chromatography and gel filtration [23, 24]. The $22.3 \mathrm{~kg} \cdot \mathrm{mol}^{-1}$ propionicin SM1 and $13.6 \mathrm{~kg} \cdot \mathrm{mol}^{-1} \mathrm{SM} 2$ were separated by gel filtration.

The yield of propionicin SM1 activity was low. About $0.4 \mathrm{mg}$ was purified, and the specific activity was only $0.5 \mathrm{AU} \cdot \mu \mathrm{g}^{-1}$. The activity in the propionicin SM2 fraction was similar, but this fraction contained much less protein and the specific activity was twelve times higher than that of propionicin SM1 [23].
Sequencing of purified propionicin SM2 gave the following $\mathrm{N}$-terminal sequence [23]:

A-T-W-S-H-S-S-L-T-N-G-A-F-H-I-R-WA-S-D-G-Y-D-V-W-Y-M.

Propionicin SM1 was also sequenced, and by use of reverse genetics the SM1 gene was identified and sequenced [24]. The gene encodes a 207-aa protein. The DNA sequence indicates that the protein is secreted by the general sec pathway and a 27-aa N-terminal signal peptide is cleaved off during the process. The gene is located on a $6.9-\mathrm{kb}$ plasmid, which was sequenced in its entirety. A gene encoding propionicin SM2 was not found in the sequence. The sequence of the $6.9-\mathrm{kb}$ plasmid is identical to that of pRG01 [16], which is found in several strains of $P$. freudenreichii, $P$. acidipropionici and P. jensenii [34].

\subsection{Bacteriocin produced by Propionibacterium jensenii B1264}

The bacteriocin was partially purified by using ammonium sulfate precipitation and anion exchange chromatography at $\mathrm{pH} 6$. Unlike most bacteriocins from Gram $(+)$ bacteria, it carried a negative charge, and isoelectric focusing indicated an isoelectric point between 3.0 and 3.5. The partially purified bacteriocin was analyzed by SDSPAGE. The inhibitory activity corresponded to either a $6 \mathrm{~kg} \cdot \mathrm{mol}^{-1}$ or $9 \mathrm{~kg} \cdot \mathrm{mol}^{-1}$ band.

This bacteriocin is heat-stable and loses no activity after heating at $100{ }^{\circ} \mathrm{C}$ for $1 \mathrm{~h}$. It was inhibitory to PAB and Lactobacillus delbrueckii strains. Interestingly, mild protease treatment stimulated its activity and extended the inhibitory spectrum to more lactobacilli as well as Lactococcus lactis [33].

The narrow spectrum of inhibition of this bacteriocin limits its usefulness in food preservation. However, Barefoot and Ratnam [2] showed that the bacteriocin can inhibit the growth of cutaneous PAB and 
suggested it as a useful agent in the treatment of acne.

\subsection{Propionicin $T 1$}

Bacteriocins with narrow inhibitory spectra are known from a number of $\operatorname{Gram}(-)$ and Gram(+) organisms. The biochemical basis for the narrow specificities is in most cases not clear, but probably involves interactions between the bacteriocins and specific receptors on the outside of the target cells [39]. Propionicin T1 is an example of such a bacteriocin. It is active against all $P$. thoenii, $P$. jensenii and $P$. acidipropionici strains tested, but no $P$. freudenreichii. Interestingly, phylogenetic analyses based on 16 S rRNA analyses [5] reveal that the sensitive species are more closely related to each other than to $P$. freudenreichii, which constitutes a separate cluster. Interestingly, in our screening of bacteriocin activity of PAB there were also strains that were inhibitory to $P$. freudenreichii strains but showed no activity against other species (unpublished results).

Propionicin T1 has been purified from P. thoenii strains 419 and LMG 2792 using cation exchange chromatography and reverse phase chromatography [7]. The peptide has 65 amino acids and its calculated pI is 9.5. Like most peptide bacteriocins it is cationic and thermostable, showing no loss of activity after heating at $100{ }^{\circ} \mathrm{C}$ for 15 min. With $P$. acidipropionici ATCC 4965 as indicator the minimal inhibitory concentration was found to be $1 \mathrm{nmol} \cdot \mathrm{L}^{-1}$, or $7 \mathrm{ng} \cdot \mathrm{mL}^{-1}$. This is similar to the minimal inhibitory concentrations found for many LAB bacteriocins [3, 13, 21]. The peptide has a bactericidal mode of action. After $4 \mathrm{~h}$ of exposure $99 \%$ of the sensitive cells are killed [7]. However, the optical density of the culture continues to rise for at least $10 \mathrm{~h}$ at a rate similar to an untreated culture, until it drops. A similar effect was observed with lactococci treated with lactococcin 972, which has been sug- gested to inhibit septum formation in lactococci [22].

The propionicin T1 gene encodes a peptide of 96 residues. The sequence of the $21 \mathrm{~N}$-terminal residues indicates that it is a signal peptide and thus the bacteriocin is secreted by the general secretory pathway.

The bacteriocin gene is preceded by a putative promoter and immediately followed by another open reading frame believed to encode the propionicin $\mathrm{T} 1$ immunity protein (see below).

Faye et al. [7] showed that exponentially growing cells of strain 419 or LMG 2792 were sensitive to their own bacteriocin. To our knowledge this has not been seen for any of the other PAB bacteriocins. As shown in Figure 2, bacteriocin production starts late in the exponential phase of growth. The finding that the cells can be sensitive to their own bacteriocin probably indicates the presence of a regulated bacteriocin immunity function. It is likely that bacteriocin production and immunity are controlled by the same mechanisms. It is very common that bacteriocin production and immunity are under the same genetic control, and the immunity gene is usually located in the vicinity of the bacteriocin gene and in the same transcriptional unit $[15,25]$.

Its location suggests that the open reading frame downstream of the propionicin T1 gene encodes the immunity factor. This gene encodes a protein of 424 amino acids. The N-terminal part of the protein shares extensive sequence similarity with socalled ABC transporters from eukaryotes as well as prokaryotes. From its sequence it is predicted that the protein is located in the cytoplasmic membrane, with four membrane spanning helixes and the N-terminal ATP binding cassette located on the inside of the cell [7].

Specific ABC transporters have been shown to be involved in immunity in a number of bacteriocin systems in $\operatorname{Gram}(+)$ as well as $\operatorname{Gram}(-)$ bacteria $[37,43]$. It is believed that the $\mathrm{ABC}$ transporter pumps the 
bacteriocin out from the cell or from the cell membrane.

\subsection{Protease-activated bacteriocins}

Bacteriocins are peptide or proteins, and protease treatment is regularly used to test if the inhibitory compound is proteinaceous. By doing this test Ratnam et al. [33] discovered that some of the inhibitory zones became larger upon protease treatment. Futhermore, the inhibitory spectrum of P. jensenii $\mathrm{B} 1264$ was broadened by protease treatment. However, prolonged treatment destroyed the activity. In our laboratory we have shown that protease $\mathrm{K}$ can activate an extracellular 225 -aa protein produced by $P$. jensenii. The protein itself has no inhibitory activity, but after protease treatment an antibacterial peptide of 65 residues is formed (Faye et al., in preparation).

\section{CONCLUSION}

From the various screenings that have been carried out it is clear that PAB can produce a number of antimicrobial compounds, and most of them still await identification. Some are bacteriocins with narrow spectra of inhibition, while others can affect a wide variety of organisms including Gram(-) bacteria and fungi.

Besides the challenge in isolating and characterizing the inhibitory compounds, there are also opportunities in exploiting them in practical applications such as food and feed preservation and medicine. This will require detailed insight into the molecular biology of PAB and the mechanisms that regulate the production of bacteriocins and other antimicrobial compounds.

\section{REFERENCES}

[1] Al-Zoreky N., Ayres J.W., Sandine W.E., Antimicrobial activity of Microgard against food spoilage and pathogenic microorganisms, J. Dairy Sci. 74 (1991) 758-763.
[2] Barefoot S.F., Ratnam P., Composition and method for treating acne, US Patent no 5.981.473, 1999.

[3] Casaus P., Nilsen T., Cintas L.M., Nes I.F., Hernández P.E., Holo H., Enterocin B, a new bacteriocin from Enterococcus faecium T136 which can act synergistically with enterocin A, Microbiology 143 (1997) 2287-2294.

[4] Daeshel M., Antimicrobial substances from lactic acid bacteria for use as food preservatives, Food Technol. 43 (1989) 164-166.

[5] Dasen G., Smutny J., Teuber M., Meile L., Classification and identification of propionibacteria based on ribosomal RNA genes and PCR, Syst. Appl. Microbiol. 21 (1998) 251-259.

[6] Ekinci F.Y., Barefoot S.F., Production of bacteriocin jenseniin G by Propionibacterium is pH sensitive, Lett. Appl. Microbiol. 29 (1999) 176-180.

[7] Faye T., Langsrud T., Nes I.F., Holo H., Biochemical and genetic characterization of propionicin T1, a new bacteriocin from Propionibacterium thoenii, Appl. Environ. Microbiol. 66 (2000) 4230-4236.

[8] Fujimura S., Nakamura T., Purification and properties of a bacteriocin-like substance (acnecin) of oral Propionibacterium acnes, Antimicrob. Agents Chemother. 14 (1978) 893-898.

[9] Furusawa E., Ramanathan S., Furusawa S., Woo Y.K., Cutting W., Antiviral activity of higher plants and propionin on lymphocytic choriomeningitis infection, Proc. Soc. Exp. Biol. Med. 125 (1967) 234-239.

[10] Gollop N., Lindner P., The propionicin PLG-1, an antibacterial peptide with a unique mode of action, 2nd Symposium on Propionibacteria, Cork, Ireland, (1998) Abstr. 14.

[11] Grinstead D.A., The detection of bacteriophages and bacteriocins among the classical propionibacteria, M.S thesis, Iowa State University, Ames, 1989

[12] Grinstead D.A., Barefoot S.F., Jenseniin G, a heat-stable bacteriocin produced by Propionibacterium jensenii P126, Appl. Environ. Microbiol. 58 (1992) 215-20.

[13] Holo H., Nilssen O., Nes I.F., Lactococcin A, a new bacteriocin from Lactococcus lactis subsp. cremoris: isolation and characterization of the protein and its gene, J. Bacteriol. 173 (1991) 3879-3887.

[14] Hsieh H.Y., Paik H.D., Glatz, B.A., Improvement of detection and production of propionicin PLG-1, a bacteriocin produced by Propionibacterium thoenii, J. Food Protect. 59 (1996) 734-738.

[15] Jack R.W., Tagg J.R., Ray B., Bacteriocins of gram-positive bacteria, Microbiol. Rev. 59 (1995) 171-200. 
[16] Kiatpapan P., Hashimoto Y., Nakamura H., Piao Y.-Z., Ono H., Yamashita M., Murooka Y., Characterization of pRGO1, a plasmid from Propionibacterium acidipropionici, and its use for development of a host-vector system in propionibacteria, Appl. Environ. Microbiol. 66 (2000) 4688-4695.

[17] Ko H.L., Pulverer G., Jeljaszewicz J., Propionicins, bacteriocins produced by Propionibacterium avidum, Zentbl. Bakteriol. 241 (1978) 325-328.

[18] Lyon G.A., Glatz B.A., Partial purification and characterization of a bacteriocin produced by Propionibacterium thoenii, Appl. Environ. Microbiol. 57 (1991) 701-706.

[19] Lyon W.J., Glatz B.A., Isolation and purification of propionicin PLG-1, a bacteriocin produced by a strain of Propionibacterium thoenii, Appl. Environ. Microbiol. 59 (1993) 83-88.

[20] Lyon W.J., Sethi J.K., Glatz B.A., Inhibition of psychrotrophic organisms by propionicin PLG1, a bacteriocin produced by Propionibacterium thoenii, J. Dairy Sci. 76 (1993) 1506-1513.

[21] Marciset O., Jeronimus-Stratingh M.C., Mollet B., Poolman B., Thermophilin 13, a nontypical antilisterial poration complex bacteriocin, that functions without a receptor, J. Biol. Chem. 272 (1997) 14277-14284.

[22] Martinez B., Rodriguez A., Suarez J.E., Lactococcin 972, a bacteriocin that inhibits septum formation in lactococci, Microbiology 146 (2000) 949-955.

[23] Miescher S., Antimicrobial and autolytic systems of dairy propionibacteria, Ph.D. thesis, ETH, Zürich, 1999.

[24] Miescher S., Stierli M.P., Teuber M., Meile L., Propionicin SM1, a bacteriocin from Propionibacterium jensenii DF1: isolation and characterization of the protein and its gene, Syst. Appl. Microbiol. 23 (2000) 174-184.

[25] Nes I.F., Holo H., Class II antimicrobial peptides from lactic acid bacteria, Biopolymers 55 (2000) 50-61.

[26] Paik H.D., Glatz B.A., Purification and partial amino acid sequence of propionicin PLG-1, a bacteriocin produced by Propionibacterium thoenii P127, Lait 75 (1995) 367-377.

[27] Paik H.D., Glatz B.A., Enhanced bacteriocin production by Propionibacterium thoenii in fedbatch fermentation, J. Food. Protect. 60 (1997) 1529-1533.

[28] Paul G.E., Booth S.J., Properties and characteristics of a bacteriocin-like substance produced by Propionibacterium acnes isolated from dental plaque, Can. J. Microbiol. 34 (1988) 1344-1347.

[29] Ramanathan S., Furusawa E., Read G., Cutting W., Isolation and activity of propionin A, an anti- viral polypeptide from propionibacteria, Chemotherapy 10 (1965) 197-204.

[30] Ramanathan S., Read G., Cutting W., Purification of propionin, an antiviral agent from propionibacteria, Proc. Soc. Exp. Biol. Med. 123 (1966) 271-273.

[31] Ramanathan S., Wolynec C., Cutting W., Antiviral principles of propionibacteria-isolation and activity of propionins B and C, Proc. Soc. Exp. Biol. Med. 129 (1968) 73-77.

[32] Ramanathan S., Furusawa E., Yee H., Cutting W.C., Propionin B, an antiviral principle of propionibacteria, Chemotherapy 19 (1973) 16-21.

[33] Ratnam P., Barefoot S.F., Prince I.U., Bodine A.B., McCaskill L.H., Partial purification of the bacteriocin produced by Propionibacterium jensenii B1264, Lait 79 (1999) 125-136.

[34] Rehberger T.G., Glatz B.A., Characterization of Propionibacterium plasmids, Appl. Environ. Microbiol. 56 (1990) 864-871.

[35] Sahl H.-G., Pore formation in bacterial membranes by cationic lantibiotics, in: Jung G., Sahl H.-G. [eds] Nisin and novel lantibiotics, Escom, Leiden, The Netherlands, 1991 pp. 347-358.

[36] Salih M.A., Sandine W.E., Ayres J.W., Inhibitory effects of Microgard on yogurt and cottage cheese spoilage organisms, J. Dairy Sci. 73 (1990) 887-893.

[37] Saris P.E., Immonen T., Reis M., Sahl H.G., Immunity to lantibiotics, Antonie van Leeuwenhoek 69 (1996) 151-159.

[38] Soumalainen T., Mäyrä-Mäkinen A., Propionic acid bacteria as protective cultures in fermented milks and breads, Lait 79 (1999) 165-174.

[39] Tagg J.R., Dajani A.S., Wannamaker L.W., Bacteriocins of gram $(+)$ bacteria, Bacteriol. Rev. 40 (1976) 722-756.

[40] Weber G.H., Broich W.A., Shelf-life extension of cultuured dairy foods, Cult. Dairy. Prod. J. 21 (1986) 19.

[41] Weinbrenner D.R., Barefoot S.F., Inhibition of yoghurt starter cultures by jenseniin $G$, a Propionibacterium bacteriocin, J. Dairy Sci. 80 (1997) 1246-1253.

[42] Yang R., Johnson M.C., Ray B., Novel method to extract large amounts of bacteriocins from lactic acid bacteria, Appl. Environ. Microbiol. 58 (1992) 3355-3359

[43] Yarmus M., Mett A., Shapira R., Cloning and expression of the genes involved in the production of and immunity against the bacteriocin lacticin RM, Biochim. Biophys. Acta 1490 (2000) 279-290. 